\title{
Pandemi Sürecinin Kadın Üniversite Öğrencileri Üzerindeki Etkileri ve Uygulanan Uzaktan Eğitim Sürecinde Yaşadıkları Sorunlar
}

\author{
DOI: 10.26466/opus.828394 \\ * \\ Emek Yıldırım Șahin * \\ * Dr. Arş. Gör., Artvin Çoruh Üniversitesi Artvin/Türkiye \\ E-Posta: emekyildirim@gmail.com \\ ORCID: $\quad$ 0000-0002-9101-8243
}

\begin{abstract}
$\ddot{O} z$
21. yüzyılın hızlı başlayan yoğun tarihi içinde bu denli geniş çaplı ve kritik düzeyde ilk salgin olma özelliğine kavuşan COVID-19 pandemisi ilk yayılım göstermeye başladı̆̆̆ dönemlerde eşitleyici bir niteliğe sahip olduğuna dair ifadelerle karşılanmıştı. Lakin zamanla pandemi sürecinin tam tersine eşitsizlikleri, mağduriyetleri, ayrımcılıkları daha da belirgin bir hale getirdiği fark edilmiştir. Özellikle işlerini, maaşlarını, gelirlerini, maddi imkânları kaybedenlerle belli bir ekonomik ve sosyal güvenceden yoksun olanlarm pandemi sürecinde yaşadıkları zorluklar zaman içinde kendini daha da gösterir olmuştur. Bu durumun mağdurlarının başında yer alan kadınlar ise hem ev içi emek yükünün artışı hem istihdam piyasasından ilk el çektirilenler olarak ekonomik imkânlarını kaybetmiş olma hem de kamusal alandan özel alana geri dönmeleri gibi yaşam pratikleri ile karşı karşıya kalmıştır. Üniversite öğrenimini sürdürmekte olan genç kadınlar ise evlerine dönmelerinin yanısıra bir de öğrenimlerini uzaktan online mecralar üzerinden devam ettirmek zorunda kalmışlardır. Bu süreçte hem ders yükleri hem de ev içi yükümlülükleri gündelik yaşamların ciddi oranda kapsamış ve pandeminin yarattığı endişe ve korkuya bu sorumlulukların psikolojik baskısı da eklenmiştir. Bu sebeple, bu çalışma, yüz yüze üniversitellisans öğrenimi sürdürürken 16 Mart 2020 tarihinde başlayan COVID-19 pandemi süreciyle evlerine dönüp eğitimlerini uzaktan yürütmek zorunda kalan kadın üniversite öğrencilerine yöneltilen sorulara verecekleri yanıtlar üzerinden hem gündelik yaşamlarının hem de akademik süreçlerinin bu pandemiden ne düzeyde ve nasıl etkilendiğini irdelemeyi amaçlamaktadır.
\end{abstract}

Anahtar Kelimeler: Pandemi, COVID-19, uzaktan eğitim, yüz yüze eğitim, üniversite, kadın, gündelik yaşam 


\title{
Effects of the Pandemic Process on the Female University Students and Problems They Lived with the Implemented Distance Education Model
}

\begin{abstract}
The COVID-19 pandemic, which is the first epidemic on such an extensive scale and in a critical level within the jump-starting intensive history of $21^{\text {st }}$ century, was first responded with statements about that it had an equalizer attribute in the period when first it began to spread. However, later it has been recognized that conversely pandemic reveals the inequalities, aggrievements and discriminations more specifically. Especially the difficulties experienced by the people who lost their jobs, wages, incomes, financial possibilities and are deprived of economic and social security, has been manifesting themselves much more in the pandemic process. Women as the foremost sufferers of this situation are confronted by such life practices as increase of domestic labor burden, having lost their economic opportunities as the foremost persons pulled out of the labor market and returning to private sphere from public sphere. Young women, who study at universities, had to continue their education by distance learning via online mediums in addition to that they went back their homes. In this process, both course loads and domestic work burdens have covered their daily life significantly, and the psychological pressure of these loads has been added to the anxiety and threat of the pandemic. For this reason, this article aims to discuss on what level and how both their daily life and their academic processes affect from this pandemic through the replies given to questions asked to female university students who had to continue their education by distance learning after they went back their homes within the COVID-19 process begun in $16^{\text {th }}$ of March, 2020 while they studies their undergraduate education face to face at university.
\end{abstract}

Keywords: Pandemic, COVID-19, distance education, face-to-face education, university, women, daily life. 


\section{Giriş}

İlk olarak 2019'un Aralık ayında ortaya çıkan yeni tip koronavirüs COVID19'un tüm dünyaya yayılması sonrası ilan edilen pandemi önlemleri kapsamında kamusal yaşam sınırlandırılmaktadır. 16 Mart'tan başlayarak başta okullar olmak üzere birçok kamu ve özel sektör faaliyet alanı kapatılmakta, belli bölgelerde belli sürelerle karantinalar, seyahat kısıtlamaları ve sokağa çıkma yasakları ilan edilmekte, 20 yaş altı ve 65 yaş üstüne ise belli zaman dilimleri haricinde bir sokağa çıkma yasağı uygulanmaktadır. Mayısın sonu itibariyle, gevşeyen önlemlerle normalleşme süreci adım adım hayata geçirilmeye başlanmasına rağmen sonbaharın gelmesiyle birlikte vaka sayıları yeniden artış göstermekte ve önlemlere geri dönülmektedir. Dünyanın her yerinden insanları ve gündelik yaşam pratiklerini derinden değiştiren pandemi süreci ilk başlarda tüm insanlığı eşitleyen bir olgu gibi ifade edilmiştir. Fakat zamanla herhangi bir eşitlik durumunun olmadığı su yüzüne çıkmaya başlamıştır. Özellikle göçmenler/mülteciler, kadınlar, yoksullar gibi pandemi öncesinde de çeşitli biçimlerde ayrımcılığa, eşitsizliğe maruz kalan madun kesimlerin pandemi sürecinde yaşadığı sıkıntılar, zorluklar bu süreçte daha da artmıştır. Bilhassa kadınların gündelik yaşamlarının pandemi süreci ile daha emek-yoğun geçtiği aşikârdır. Ev içi ve dışı hijyene daha çok dikkat edilmesinden, gerektiği koşullarda evde yaşlıların, engellilerin, hastaların ve/veya çocukların gündelik bakımlarına; çocukların uzaktan eğitim ile devam ettikleri öğrenimleriyle ilgilenmeye kadar, pek çok ilave işle kadınların ev içi emek yükleri ciddi oranlarda artış göstermiştir. Ayrıca, kadınların önemli bir kısmı işini, maaşını, ekonomik ve toplumsal özgürlük alanını, kamusal hayat içindeki yerini ve kendi yaşamı üzerindeki söz hakkını da kısmen kaybetmiş durumdadır. Çünkü pandeminin ortaya çıkmasıyla emek piyasalarından olduğu kadar kamusal yaşamdan da çıkarılan, uzaklaştırılan ilk kesim kadınlar olmuştur. Diğer bir deyişle, belirtmek gerekirse "krizlerin cinsiyeti vardır" (Korolczuk, 2020). Öte taraftan, aynı zamanda bir anlamda koine' den ${ }^{1}$ oikos $^{2}{ }^{2}$ geri dönen kadınlar bu sefer oikos'un tüm sorumluluklarının yanına koine' den

\footnotetext{
${ }^{1}$ Antik Yunan'da oikos "ev, hane, aile" manasına gelmektedir. Sosyolojik bazda ise, oikos kavramı kadınlarla kölelerin gündelik yaşamlarını ve işlerini yürütmelerine izin verilen özel alana karşılık gelmektedir. ${ }^{2}$ Koine ise yine Antik Yunan'da "ortak" manasına gelmektedir. Bu kavram da, oikos dışında kalan Polis'teki ortak kullanım alanlarını ya da başka bir deyişle kamusal alana karşılık gelmektedir.
} 
getirdikleri yükümlülükleri de ekleyip pandemi sürecini kayda değer bir uğraş ve çaba içinde geçirmektedirler.

Bir diğer yandan, bu kadınların bir kısmını oluşturan genç kadınlar, -annelerinden ve ninelerinden farklı olarak- modern dünyanın yeni türden sosyo-ekonomik ve sosyo-kültürel yapısının şekillendirdiği kendilerine has ontolojik ve epistemolojik konumlanmalarını da bu süreçte alışık olmadıkları bir biçimde yeniden formüle etmek zorunda kalmışlardır. Dünya çapında yükselen feminist hareketin önemli bir bileşeni olan genç kadınların, hâlihazırda sahip olduğu emek piyasasının daralmasına, işsizliğin artmasına ve yaklaşan ekonomik krizlerin sebep olduğu gelecek kaygısına ek olarak, yaşamlarını anlamlandırdıkları toplumsal ve kültürel referans noktaları da tehdit altındadır. Özellikle hem sosyo-ekonomik kaygılarının hem de sosyo-kültürel birikimlerinin yeniden formülize edildiği alanlardan birisi olan üniversitelerin eğitime ara vermesi bu genç kadınların yaşamında kritik bir değişime de yol açacaktır. Üniversiteler genç kadınlar için sadece ders dinlemek için gidilen bir mekân olmayıp aynı zamanda onların özellikle gelecekte sosyo-ekonomik ve sosyo-kültürel dayanak noktalarını sağlamlaştıracak birikimi de onlara sağlayabilecek bir yaşam alanıdır. Bu nedenle, pandemi nedeniyle üniversitelerin yüz yüze eğitime ara verip 2019-2020 eğitim-öğretim yılının bahar döneminin büyük bir kısmını ve 2020-2021 güz döneminin tamamını uzaktan eğitim ile online olarak yürütmeleri, kadın öğrenciler için hem gündelik yaşamları hem akademik yaşamları için önemli bir zaman dilimini de imlemektedir. Çoğunlukla evlerinden uzakta üniversite hayatı yaşayan ve bu süreçte bir anlamda kendi yaşamlarını, kişiliklerini, geleceklerini de kuran kadın öğrencilerin pandemi dönemiyle evlerine geri dönmeleri, evde kapalı kalmaları ve doğrudan ev içi emek sürecinin içine girmeleriyle eşzamanlı olarak uzaktan eğitim ile öğrenimlerini yürütmeye çalışmaları üstlerine ciddi bir yük yüklemiştir. Pandeminin ve karantinanın yarattığı psikolojik baskıya ve gelecek günlerin belirsizliğinin endişesine ek olarak bu yükün yarattı̆̆ 1 zorluklar kadın öğrencilerin daha da zor bir dönem geçirmesine yol açmıştır. Bu nedenle, bu çalışma ile, kadın öğrencilerin bu süreçte karşı karşıya kaldığı zorluklar ve bu zorlukların yaşamlarındaki tezahürleri irdelenmeye çalışılacaktır. 


\section{Pandemi Sürecinde Kadınların Durumu}

Tüm dünya üzerinde sürekli 'evde kal' çağrılarının yapıldığı pandemi sürecinde, ev, salt günün belirli zamanlarında ihtiyaçların karşılandığı bir mekân olmaktan çıkıp gündelik yaşamın büyük bir kısmının belirlendiği bir yer halini almıştır. Ev, sadece aileyi oluşturan bireylerin belki de hayatlarında ilk defa hep beraber uzunca bir süre bir arada oldukları ve tüm yaşamlarının her anını paylaştıkları bir yer haline gelmiştir. Bu durum ise elbette evin anlamında ve yapısında bir dönüşüme yol açmıştır. Ev içi toplumsal cinsiyet eşitsizliğinin daha görünür olduğu, şiddetin ve baskının belirginleştiği bu dönemde ev, kadınlar için adeta bir demir kafes halini almıştır. 'Yeni normal' olarak adlandırılan pandemi sonrası dönemde kadınların ev ve evdeki diğer bireylerle kuracağı ilişki aynı zamanda yeni normalin de açılımını verecektir. Hatta, bir anlamda "yeni normalin de evle ilişkimiz bağlamında ele alınması önemli bir sosyopolitik ve etik görev" halini alacaktır, "[h]ele de evin, konuttan başlayıp ülke, yurt, coğrafya, toprak, hatta ulus-devlete 'genişleyebileceği' ve böyle bir genişlemenin 'dağılma ve yersizliğe' varabileceği göz önüne alındığında" (Düzen ve Gezici-Yalçın, 2020).

Yeni normal ile yaşamın daha da yoğunlaşacağı ortam olarak evin aynı zamanda kadınların yoğun mesaisiyle işleyen bir yer olması dolayısıyla, bu yeni dönemde kadınların yaşam ve çalışma koşullarında da önemli değişiklikler olacağı açıtır. Bu dönüşümün ataerkil kodların güçleneceği yönde mi yoksa bu kodların aşılacağı yönde mi ilerleyeceği ise kadınların gelecek günlerde toplumsal cinsiyet eşitsizliği hususunda yaşayacakları deneyimler ve bunlara verecekleri tepkiler ve mücadeleler üzerinden yeniden tariflenecektir. Pandemi süreciyle önemli değişimlere gebe gelecek günlerde kadınların yaşamları yeni normalden etkilenecek ama bu etkilenmenin izleyeceği seyir evin alacağı bağlam ve kadınların evdeki konumları ile doğrudan bağlantılı olacaktır. Oikosun kazanacağı yeni bağlam ve koine ile olan ilişki içinde kadınların konumlanmaları kadınların geleceğini de belirleyecek faktörlerden olacaktır. Özellikle de istihdam piyasasının en zayıf halkasını oluşturan ve ev içi emeği verecek başkarakter olan kadınların pandemi sürecinde deneyimledikleri pratikler yeni normal ile sosyo-ekonomik ve sosyo-kültürel yapının da dönüşüme uğrama sinyallerini vermiştir. BM Kadın Birimi İcra Direktörü Phumzile Mlambo-Ngcuka'nın ifade ettiği gibi: "Pandemi, sağlığın çok öte- 
sine geçen, sosyal ve ekonomik yapılarımızı biçimlendirme yollarımızı kökten sarsan bir krize neden oldu. Kadınlar daha az kazanıyor, daha az tasarruf ediyor, daha güvencesiz işlere sahip, daha çok kayıtdışı ekonomide çalışıyor ve sosyal korumaya daha az erişebiliyorlar" (ILO, 2020). Bu nedenle de, bir anlamda "' $\mathrm{h}]$ ane halkına bakım verme' ile 'para kazanma' arasında denge kurma çabası zorlaştığında, kadınlar zor kararlar vermek zorunda kalacaklar. Ve bu kararlar çoğunlukla onların aleyhine işleyecektir" (Junaid, 2020).

Diğer bir deyişle, pandemi süreci ile kadınlar evlerde yaşlılara, hastalara, çocuklara bakıp, hijyen kurallarına göre tüm evi baştan sona temizleyip, evdeki aile bireyleri için yemekler yapıp, daha sık kirlenen bulaşıkları ve çamaşırları yıkayıp, evin ve ailenin dirliği için tüm gün aralıksız olarak ücretsiz ve güvencesiz bir biçimde çalışırken, aynı zamanda kendi mesleklerinden, işlerinden, kariyerlerinden, gelirlerinden, zamanlarından, hobilerinden de feragat etmek zorunda kalmaktadırlar. "Dünya genelinde ev ve bakım işlerini kadınlar erkeklere oranla 3 kat daha fazla üstleniyor. Türkiye'de ise bu sayı neredeyse 5 kata ulaşıyor. COVID-19 salgını sebebiyle ailelerin evde kalması kadınların üstlendikleri ev ve bakım işini daha da artıyor. Diğer yandan evden çalışan kadınlar hem iş hem bakım yükünü aynı anda yürütmeye çalışıyorlar. Bu durum çalışma saatlerini artırmış" durumdadır (BM, 2020a). Bir diğer taraftan, 'evde kal' sloganının arkasında yatan başka bir anlam ise kadınların bir tür "eve geri itilme" halinin olduğunu söylemek mümkündür (Ayanoğlu, 2020). Lakin aynı zamanda emek piyasalarının en güvencesiz, en esnek, en düşük ücretli kesimi olan kadınlar, salgının yayılım göstermesi ve karantina koşullarının uygulanmaya başlaması ile ya işgücü piyasasından ayrılmak ya da kalıp en güvencesiz işlerde çalışmak zorunda kalan kesim olmuştur. ILO Genel Direktörü Guy Ryder' in de belirttiği gibi: “COVID-19 pandemisi, bu pandeminin çalışan kahramanlarının her zamanki vazgeçilmez rolünü bir kez daha ortaya çıkardı. [...] Onlar genelde görülmeyen, düşünülmeyen, yeterince değer verilmeyen, hatta göz ardı edilen insanlar. Bu kişiler; sağlık ve bakım çalışanları, temizlikçiler, market kasiyerleri, evlerinde ve toplumlarında ücretsiz bakım işleri yapanlar - büyük çoğunluğu kadın, sıklıkla göçmen işçiler ki bu kesim çok daha sıklıkla çalışan yoksullar ve güvencesizler arasinda yer alıyorlar"' (ILO, 2020).

Bunun ilk sebebi kadınların hala istihdam alanında ikincil konumda olmaları nedeniyle bir kriz anında iş feshinin daha kolay yapılıyor olması ve 
işverenin kadın çalışanlarından erkeklere oranla daha kolay vazgeçiyor olmasıdır. İkinci sebebi ise, evde bakım emeğinin kadının yükümlüğü olması ve bu yükümlülüğü yerine getirmek için kadınların kamusal alandan özel alana geçiş yapmak zorunda kalmasıdır. Bununla birlikte, buradaki esas sorun pandemi süreci sonrasında kadınların yeniden istihdam alanına geri dönme imkânını bulup bulamayacaklarıdır. Pandemi sonrası süreçte kadınların hem emek piyasalarındaki hem de kamusal alandaki mevcudiyetlerinin düzeyi, bu dönemde ortaya çıkması muhtemel ekonomik, siyasal ve/veya toplumsal krizlerin yol açacağı bir ortamda artan rekabet ile güvencesiz ve esnek çalışma koşullarının baskısı altında şekillenecektir. Bu bağlamda, Simon Fraser Üniversitesi'nde sağlık politikaları üzerine çalışan Dr. Julia Smith'e göre, "salgın dönemlerinde kadınlar evde kalmak için işlerini ve gelirlerini bıraktıkları zaman kriz sonrasında yeniden dönmeleri hayli zor olmaktadır" ve örneğin "Batı Afrika' da ortaya çıkan Ebola salgınından gelir bazında herkes etkilenirken, erkeklerin geliri salgın öncesi düzeye kadınlarınkinden daha hızlı bir biçimde geri dönmüştür" (Gupta, 2020).

Böylelikle, tüm dünyada pandemi sürecinin sosyo-ekonomik ve sosyokültürel arkaplanının ortaya çıkarılmasında, evin/hanenin adeta bir örneklem görevi görmesiyle, toplumsal cinsiyet eşitsizliğinin hayatın her alanında daha belirgin bir biçimde fark edilebileceği ortadadır. Örneğin, Birleşmiş Millletler'in (BM) yayınladığ1 09 Nisan 2020 tarihli COVID-19'un Kadınlar Üzerindeki Etkisi Politika Özeti'ne göre, gün içinde kadınların bakım emeğine harcadığ ortalama vakit 4,1 saat iken bu erkeklerde ortalama 1,7 saat şeklinde tezahür etmektedir ve salgin süresince özellikle çocuklar, yaşlılar ve hastalar başta olmak üzere tüm aile bireyleri için ve hizmet sektörünün salgınla ilgili kesimleri için gerekli olan bakım emeğine olan ihtiyacın katlanarak artmasıyla "[p]andemi bağlamında ise bakım işine olan artan talep emeğin toplumsal cinsiyete dayalı dağılımındaki eşitsizlikleri daha da derinleştirmektedir" (BM, 2020b, s. 13-14). Aynı zamanda, bu hususta yapılan çeşitli araştırmaların da ortaya koyduğu gibi, insanlık tarihinde ortaya çıkan "pandemilerin cinsiyet eşitliği üzerinde derin ve uzun vadeli etkileri olduğu sonucuna" varmak mümkündür (Junaid, 2020). Başka bir deyişle, bu pandemi süreci kadınların içinde bulundukları koşulları ve ataerkil kodları, toplumsal normları da sorgulayacakları bir dönem olma niteliğini de taşımaktadır. Doğrusu, bu süreç aynı zamanda kadınların yaşam ve çalışma koşullarının iyileştirilmesi, özel 
alana sıkışıp kalmadan kamusal alanda da varlıklarını sürdürme mücadelesinin yükseltilmesi, ev içi emek yükünün paylaşılmaya başlanması gibi birçok başlığ1 da toplumların gündemine taşıyacak imkâna, potansiyele de sahiptir. Böylesine bir dönüşüm kadınlar için distopik geleceğin kurulmasının önündeki en önemli adımlardan da biri olacaktır.

\section{Araştırmanın Amacı ve Önemi}

Bu çalışma, kadın öğrencilerin hem pandemi sürecinde hem de pandemi nedeniyle hayata geçirilen uzaktan eğitim sürecinde yaşadıkları sıkıntıları ortaya koyarak bu süreçte gündelik hayat pratiklerini ve bu pratiklerin yarattı̆ 1 zorlukları irdeleme gayesiyle yapılmaktadır. Dolayısıyla, öğrenim gördükleri üniversiteyi ve yüz yüze eğitimi arkalarında bırakıp ülkenin çeşitli yerlerindeki evlerine dönüp öğrenimlerine online olarak uzaktan eğitimle devam eden kadın üniversite öğrencilerine yöneltilen sorulara verdikleri yanıtlar üzerinden pandemi sürecinde gündelik yaşam ve öğrenim koşul ve ortamlarının incelenmesi amaçlanmaktadır.

Bu bağlamda, ağırlıklı olarak taşrada yaşayan genç kadınların lisans eğitimleri için evlerinden uzakta bir yere gelip burada öğrenimlerine devam ederken küresel çapta ortaya çıan bir salgınla beraber evlerine geri dönmeleri ve evde önceden geçirdikleri zamanda daha fazla zaman geçirmeleri sonucunda gündelik yaşamlarında ortaya çıkan sorunlar ile pandemi nedeniyle uygulamaya konan uzaktan eğitim modeliyle birlikte öğrenimleri nezdinde yaşadıkları sıkıntılar Türkiye' de üniversite eğitimini sürdüren yüzlerce, binlerce genç kadının ortak deneyimi halini almıştır. Bundan dolayı, çalışmanın dayandığı sorunsal, karantina koşullarının yarattı̆ı zorluklara ek olarak pandemi sürecinde uygulanan uzaktan eğitim modelinin getirdiği sıkıntıların kadın üniversite öğrencilerinin gündelik yaşamlarına muhtemel etkilerinin ele alınması üzerinden bir anlamda hem pandemi sürecinin hem de pandemi sonrası sürecin genç kadınların yaşamlarında yaratacağı dönüşümü ortaya koyma çabasında yatmaktadır. Bu çalışmanın önemi ise, pandemi ile ortaya çıkan tüm bu etmenlerin, bu genç kadınların şimdiki ve gelecekteki günlerini ciddi bir biçimde etkileyebilecek bir potansiyele sahip olmasıdır. Bu nedenle, bu çalışma bu potansiyelin neden ve sonuçlarını bir nebze de olsa gözler önüne sermek için yapılmıştır. Bu çalışma, bir anlamda pandemi sürecinin kadınlar üstündeki etkilerini inceleyen çalışmalar arasında yerini alacak ve 
üniversite çağındaki genç kadınların pandemi sürecinden ne türlü olumsuzluklarla çıkacağına dair bir inceleme gelecekte hem bu konuda yapılacak çalışmalara hem de bu hususta alınacak muhtemel önlemlere bir kapı aralayacaktır. Genel olarak, literatür bağlamında ise, ilk olarak özellikle kadın öğrenciler ve onların karşı karşıya olduğu toplumsal cinsiyet eşitsizliği durumlarıyla ilgili çalışmalara, ikinci olarak pandemi sürecinin kadınlar ve gençler üzerindeki etkilerini ele alarak genel anlamda pandemi literatürüne katkı sağlamayı amaçladığını söylemek mümkündür.

\section{Araştırmanın Yöntemi ve Verilerin Toplanması}

Çalışmanın evrenini kadın üniversite öğrencileri oluştururken, örneklemi ise Artvin Çoruh Üniversitesi Siyaset Bilimi ve Kamu Yönetimi Bölümü'nde 2019-2020 bahar döneminde verilen Siyaset Sosyolojisi ve Siyaset Psikolojisi derslerini alan kadın öğrencilerden oluşmaktadır. Aynı zamanda bu öğrencilerin bir kısmı güz döneminde de (yazarın açmış olduğu) seçmeli Toplumsal Cinsiyet dersini de almış öğrencilerdir. Bahar döneminin büyük bir kısmını kapsayan uzaktan eğitim süreci bu iki dersin Google Classroom üzerinden asenkron olarak haftalık okumalar verilerek ve ilgili konulara dair verilen soruları yanıtlayan haftalık kısa ödevler ile yürütülmüştür. Bu süreçte öğrencilerin hem pandemiden hem de pandemi sürecinde yürütülen uzaktan eğitim uygulamalarından çeşitli biçimlerde muzdarip oldukları görülmüştür. Bunlar evlerde internet ve bilgisayarın olmaması, karantina altında yaşamanın verdiği psikolojik baskı, ev içi emek süreçlerine dâhil olma, pandeminin sebep olduğu anksiyete sorunları, ekonomik zorluklar gibi sıkıntılardır. Bu süreçte, bu öğrenciler hem kadın hem de genç olmanın dezavantajlarıyla doğrudan yüz yüze kalmışlardır. Bu sebeple, bu çalışma, yüz yüze üniversite/lisans öğrenimi sürdürürken 16 Mart 2020 tarihinde başlayan COVID-19 pandemi süreciyle evlerine dönüp eğitimlerini uzaktan yürütmek zorunda kalan kadın üniversite öğrencilerine yöneltilen sorulara verecekleri yanıtlar üzerinden hem gündelik yaşamlarının hem de akademik süreçlerinin bu pandemiden ne düzeyde ve nasıl etkilendiğini irdelemeyi amaçlamaktadır. Bu nedenle, 2019-2020 bahar döneminin büyük bir kısmında öğrenimlerini pandemi nedeniyle uzaktan eğitim modeliyle yürüten Artvin Çoruh Üniversitesi Siyaset Bilimi ve Kamu Yönetimi Bölümü 3. ve 4. sınıftaki kadın öğrencilere, uzaktan eğitimle tamamlanan bahar döneminin sonu itibariyle, Haziran 2020 
tarihinde Google Forms'da hazırlanan yapılandırılmış ve yarı-yapılandırılmiş sorulardan oluşan bir anket formu iletilmiştir. Bunun yanında, etik kurul izni için 19 Haziran 2020 tarihinde yapılan başvuru sonucunda 24 Haziran 2020 tarihli ve 78646441-050.01.04 sayılı Etik Kurul Kararı alınmış ve çalışma etik olarak onaylanmıştır.

Genel olarak, öğrencilere, içinde bulundukları standart yaşam koşullarını betimlemeye yarayacak demografik soruların yanısıra pandemi sürecinin gündelik yaşamlarını nasıl etkilendiğine dair ve uygulanan uzaktan eğitim modelinin öğrenimlerine etkisini ele alan sorular sorulmuştur. Aynı zamanda çalışmanın seyrini daha sarih bir biçimde götürebilmek için, çalışma ile doğrudan bağlantılı olmasa da ya da veri seti içinde önemli bir yer tutmasa da, formu oluşturan 50 soru içinde bazı ayrıntıları irdeleyen sorular da sorulmuş ve bu şekilde öğrencilerin ankete odaklanıp kendilerini daha rahat ifade etmeleri amaçlanmıştır. Çalışmanın gönderildiği 50 öğrenciden 33'ü anketi yanıtlamıştır. Diğer yandan, genel olarak öğrencilerin bilgisayar ortamına ve internete ulaşmada yaşadıkları sıkıntılar göz önüne alınırsa zaten beklenilen bir rakama da ulaşılmışır. Ayrıca, Google Forms'un opsiyonel yapısı sayesinde, anket, yanıtların hangi öğrenciden geldiği belli olmayacak şekilde hazırlanmış ve yanıtlar alınmış ve derlenmiştir. Cevaplarını daha rahat bir biçimde verebilmeleri için, öğrencilere kimliklerini gizli tutma imkânı verilmiştir. Öğrenci yanıtları gelme sırasına göre Y1, Y2, Y3, vb. şeklinde kodlanmış ve metin içinde bu kodlara atıf yapılarak kullanılmıştır. Lakin, soruların ve yanıtların niceliksel ve niteliksel yoğunluğu ve basım/yayın kısıtları nedeniyle bu makalede tüm sorular ve yanıtlar ele alınmamış; çalışmanın sorunsalını ortaya koyacak biçimde bir kısmı irdelenebilmiştir.

Çalışmanın oluştuğu toplamda sayısı 50'yi bulan sorulardan 24 tanesi uzun cevaplı, 5 tane kısa cevaplı, 15 tane çoktan seçmeli ve 6 tane de oransal ölçekli sorulardır. Bu yönteme, salt nicel bir çalışma olması yerine, nitel ve nicel verilerin bir arada olduğu bir veri seti elde etmek için başvurulmuştur. Bu nedenle de, uzun cevaplı sorulara ağırlık vererek öğrencilerin içinde oldukları koşulları rahatlıkla ifade etmeleri için alan sağlamaya çalışılmıştır. Ankette sorulan soruların formatı ise dört farklı biçimde hazırlanmıştır. Bunlar: Kısa yanıt; uzun yanıt; çoktan seçmeli; ve evet-hayır seçeneklerinin 1'den 5'e oranlanması ile oransal ölçeklendirme kullanılmasıdır. Kısa yanıtlı sorular genellikle belli bir sayı/rakam gerektiren sorulardır. Uzun yantlı sorular ise, daha çok öğrencilerin kendilerini ve içinde bulundukları koşulları daha 
detaylıca betimlemeleri için hazırlanan sorulardır. Çoktan seçmeli sorular, genel olarak sorunun sorduğu hususu ortaya koyacak biçimde belirlenmiş sözcükler arasından katılımcıların koşullarına uygun olanı/olanları seçmesi istenen sorulardır. Oransal ölçeklendirme kullanılan sorular da, içinde oldukları koşulların niteliğini ve/veya katılımcıların bu koşullara dair duygu ve düşüncelerini olumludan olumsuza uzanan bir oranlama ile değerlendirmeleri istenen sorulardır. Bir yanda öğrencilerin deneyimlediği bu koşulların özelliklerine, diğer yanda onların bu deneyime dair duygu ve düşüncelerinin niteliklerine dair sorulan sorularla, pandemi sürecinde kadınların yaşadıkları genel problemler arasından derlenen ve katılımciların bireysel deneyimleri üzerinden ortaya çıkan mevcut durumu betimleme imkânı yaratılmaya çalışılmıştır.

Bir diğer taraftan, bu çalışma bağlamında feminist metodolojiye uygun bir yaklaşım benimseyerek, kadınların "kendi pozisyonundan, süreçleri biricik şekilde deneyimlediği ve öznel deneyimlerin de genellemeler kadar değerli ve bir o kadar "gerçekliğe" ait olduğunun altını çizme[nin]" faydası vardır (Göker ve Polatdemir, 2019, s. 9). Bir anlamda, "[f]eminist epistemolojinin temel kavramlarından biri olan Feminist Duruş Noktası; erkek merkezli kurumsallaşmış güç ve bilginin yarattığı hiyerarşiyi yıkmak, ezilen grupların sesini duyurarak güçlenmelerini sağlamak gibi amaç ve hedefler taşır" (Harding, 2007 akt. Bilir, 2021). Diğer bir deyişle, "çünkü feminist duruş noktası anlayışında evrensel bir özne değil, öznellikler mevcuttur" (Altınok, 2018, s. 61). Bu bağlam dahilinde, sadece bireysel deneyimlerin kolektif ve politik niteliğini ortaya çıkarmakla kalmayıp, buna dair bir neden-sonuç ilişkilerinin serimlenmesinin yanısıra kadınların bu deneyimlerinin barındırdığı ve esasinda kolektif bir karaktere sahip olan soruna çözüm üretme ve yanit bulma olanakların da vermektedir. Bu minvalde hem feminist kuramda hem de feminist pratikte oldukça önemli bir yer tutan ve 'kişisel olan politiktir' mottosuyla da altı çizilen kadınların bireysel/şahsi deneyimlerinin kolektif ve politik yanının sahip olduğu önem bu çalışmanın da odağına aldığı noktalardan biridir. Bu sebeple çalışma içinde kadın öğrencilerden gelen yantlara bizzat yer verilmesinin sebebi ise, tam olarak onların kendi ifadelerine başvurarak örneklem grubunun sesinin duyulmasını daha direkt olarak sağlama isteğidir. Aynı zamanda, araştırmacının, bu çalışmanın kadın öğrencilerin bu sürece dair deneyimlerini ve yaşadıkları zorlukları, sıkıntıları ifade edebilecekleri bir zemin olmasını da amaçladığını vurgulamak gerekir. 


\section{Bulgular}

\section{Katılımcılarm Betimsel Özellikleri}

Çalışmaya katılım gösteren kadın öğrencilerin, ağırlıklı olarak 20'li yaşlarının başlarında yer almakta oldukları görülmektedir. Mod değer ise 11 kişi ile 22 yaştır. Dolayısıyla, katılımcı grup pandemi sürecinde uygulanan 20 yaş altı sokağa çıkma yasağına da maruz kalmamış ve ev dışına çıkma konusunda kısıtlama yaşamamışlardır. Ancak, gelen yanıtlardan anlaşıldığı kadarıyla, bu kadın öğrencilerin yaşları gereği evde üstlendikleri ev içi emek yükü ve ataerkil kodlar nedeniyle yaşıtları erkeklere göre sokağa çıkma konusunda daha kısıtlı imkânları olduğunu da söylemek mümkün.

Katılımcılardan 9'u köyde, 8'i ilçe merkezinde, 7'si il merkezinde, 6'sı metropolde ve 3'ü de büyükşsehirde ikamet etmektedir. Buradan da anlaşılacağ1 gibi, öğrenciler ağırlıklı olarak taşraya ait sosyo-ekonomik ve sosyo-kültürel bir arkaplana sahip oldukları ve hane içi ilişkilerin de buna uygun biçimde şekillenmesi beklenmektedir. Böylesine bir arkaplana sahip oldukları düşünülen öğrencilerin bu arkaplanlarının daha da serimlenmesi için annelerinin ve babalarının eğitim durumları da sorulmuştur. Katılımcilardan 19'unun annesi ilkokul mezunu, 6'sı okuma-yazma bilmiyor, 4'ü okuma-yazma biliyor ve 4'ü de ortaokul mezunudur. Diğer yandan, çalışmaya katılım gösteren 33 öğrenciden 17'sinin babası ilkokul, 7'si ortaokul, 7'si lise mezunu ve 2'si ise sadece okuma-yazma biliyor. Bunlara ek olarak, katilımcların hanelerinin aylık gelir düzeyleri de sorulmuştur. gelen 33 yanıtın ortaya koyduğu tabloya göre, 16 katılımcının aylık hane geliri 2.000-3.999 TL, 9'unun 0-1.999 TL, 7'sinin 4.000-6.999 TL, 1'inin de 7.000-9.999 TL. Buna göre, 33 katılımcinın yarısından fazlasının yani 27 'sinin aylık hane geliri 4.000 TL'nin altındadır. TÜRK-IŞS Sendikasının Aralık 2020 için açıkladığ 1 dört kişilik bir aile için güncel açlık sınırının 2.591 TL ve yoksulluk sınırının 8.463 TL olduğu göz önüne alınırsa (TÜRK-İS, 2020), bu verilerin de ortaya koyduğu gibi, öğrencilerin çoğunluğu yetkin bir sosyal ve kültürel sermayeye sahip olmayan ve sosyoekonomik olarak alt ve alt-orta siniftan ailelerden gelmektedir. Bu tablonun iyimser yanı ise ağırlıklı olarak düşük bir gelire ve maddi sıkıntıların yoğun olma olasılığının yüksek olduğu bir ekonomik duruma sahip ailelerin kız çocuklarının üniversite eğitimi almalarını sağlamaya çalısmalarıdır. Bu kadın öğrenciler geldikleri arkaplanların tüm dezavantajlarına rağmen üniversite 
eğitimi alarak gelecekleri hususunda önemli bir adım atmaya çalışmaktadırlar. Filhakika, bu çaba hem öğrencinin hem de ailenin verdiği maddi-manevi birçok bedel ile ortaya konabilmektedir. İstihdam alanında ortaya çıkmış durumda olan artan rekabet, yüksek işsizlik oranları ve kadın işgücünün yeterince güvenceye kavuşmakta zorlanıyor olması yine de bu bedellerin ödenmesinden aileleri vazgeçirmemiştir. Çünkü eğitim hala Türkiye'de sosyokültürel ve sosyo-ekonomik anlamda bir seviye atlama aracı olarak görülmektedir ve bu intiba toplumun her kesiminde mevcudiyetini korumaktadır.

Bunun ardından, diğer bir husus da ailenin diğer üyeleri ve hanenin yapısıdır. Katılımciların 11'i 2 kardeşe sahipken, 9'u 3-4 kardeşe, 7'si 5 ve daha fazla kardeşe, 6'sı ise 1 kardeşe sahiptir. Bunun yanında, öğrencilerin ağırlıklı olarak sahip oldukları sosyo-kültürel yapı göz önüne alındığında hane nüfusunun çekirdek ailenin ötesinde olma beklentisi yine öğrencilerin birlikte yaşadıkları hane halkının daha detaylıca betimlenmesini öğrenme gereğini doğurmuştur. Ayrıca kalabalık bir hane aynı zamanda yapılacak daha çok iş de demektir ve genç kadınlara bu ev içi iş yükünden ciddi bir oranın düşme ihtimalinin ise yüksek olacağı açıktır. Bu çalışmanın bir boyutunu da oluşturan bir husus olarak, kadınların pandemi sürecinde sürekli evde olan tüm hane üyelerinin meydana getirdiği ev nüfusunun kalabalık olması aynı zamanda çalışmaya katılım gösteren genç kadınların da gündelik yaşamlarının ev içi iş yükü ile dolup, uzaktan yürütülen eğitimlerine yeterince çaba ve özen gösterememelerine de yol açacağ 11'inin ailesi 4 kişiden, $7^{\prime}$ sinin 5 kişiden, 6'sının 3 kişiden, 4'ünün 6 kişiden, yine 4 'ünün 7 ve üstü kişiden, 1'nin de 2 kişiden oluşmaktadır. Çekirdek aile dışında hanede yaşayanların sorulduğu soruya gelen yanıtlara göre ise, 33 katılımcıdan 27'sinin hanesi çekirdek aile üyelerinden oluşurken, 3'ünde kardeşlerin eşleri ve yeğenler, 2'sinde babaanne/anane ve/veya kuzenler, 1'inde dede/büyükbaba, amca/dayı ve/veya hala/teyze haneye dahildir. Bu verileriden ortaya çıkan sonuç ise, katılımcıların ağırlıklı olarak çekirdek aile halinde yaşadığıdır. Bu resmin muhtemel olumlu yanı genç kadınların gündelik yaşamlarında kendilerine ayırabilecekleri hem zamanın hem de mekanın var olma ihtimalinin yüksek olmasıdır. Muhtemel olumsuz yanı ise genç kadınlar üstündeki ev içi iş yükünün nispeten daha az olma olasıllğına karşı aile bireylerinden gelir kazananların çeşitli biçimlerde evden ayrılması sonucu hanenin aylık gelirinin ve ailenin sosyo-ekonomik durumunun zayıflaması 
ve bunun da evde eğitimlerini sürdürmek için gerekli olabilecek bazı imkanları sağlama bakımından bir dezavantaj yaratması olabilir.

\section{Pandemi Süreci ve Uzaktan Eğitim}

Bu durum, görüngesel bir ekrana kalıcı olarak hapsedilen ve herhangi bir hayat deneyiminden dışlanmayı deneyimlediğimiz teknolojik barbarlığın bir parçası. Yaşananlar üzerinde çok daha belirleyici olan ancak hiç konuşulmayan bir şey var; bir yaşam tarzı olarak studentate'nin sona ermesi. Üniversiteler Avrupa'da universitates'ten (öğrenci birlikleri) doğdular ve isimlerini bu birliklere borçlular. Öğrencilik, her şeyden önce, elbette ders çalışmanın ve dersleri dinlemenin kesinlikle belirleyici olduğu fakat genellikle uzak yerlerden gelen ve milliyetlerine göre bir araya gelen bilginlerin (scholars) devaml görüşmelerinin de önemli olduğu bir yaşam biçimiydi. Olgunun toplumsal boyutu olan bu yaşam tarzı, Orta Çă̆'daki gezgin din adamlarmdan yirminci yüzyılın öğrenci hareketlerine kadar yüzyıllar boyunca çeşitli şekillerde ama sürekli olarak gelişti. Bir üniversite sinıfinda ders veren herkes, arkadaşliklarn, ders sonunda bile devam eden politik ve kültürel araştırma gruplarıla iç içe geçtiğini bilir. Neredeyse on yüzyıl süren bu durum şimdi sonsuza dek sona eriyor. Öğrenciler artık üniversitenin bulunduğu şehirde yaşamayacaklar, ancak her biri kendi odasinda kapal bir şekilde dersleri dinleyecek ve önceden sinıf arkadaşlarn olan kişilerden bazen kilometrelerce uzakta olacaklar. Bir zamanlar prestijli üniversitelere ev sahipliği yapan küçük şehirler, çoğu zaman şehrin en canlı kısmı oluşturan öğrenci topluluklarının sokaklardan kayboluşunu izleyecek (Agamben, 2020a).

COVID-19 pandemisinin 2019 Aralık ayında Çin'de ilk ortaya çıkması ve sonrasında 2020'nın Şubat-Mart ayları itibariyle tüm dünyaya yayılmaya başlaması ile dünya sathında salgının yayılımını engellemek için karantina uygulamasına gidilmiştir. Bu nedenle, sağlık ve temel gıda sektörü haricinde başta eğitim sektörü olmak üzere tüm kamusal alanlarda uygulanan karantina ile herkes evlerine dönmüş ve hayat bir anda duruvermiştir. Bu durumdan, Türkiye' de sadece yükseköğretim alanında 3 milyon 777 bin 114 öğrenci ve aileleri etkilenmiştir (Göğüş-Tan, 2020). 2019-2020 Bahar Dönemi'nin ortasında derslere üç hafta ara verilmiş fakat sonrasında eğitimin uzaktan yürütüleceği açıklanmasına rağmen 2020-2021 Güz Dönemi'nde de uzaktan eğitim ile devam edilmiştir. Lakin, pandeminin genel toplumsal eşitsizlikleri ve ayrımcılıkları su yüzüne çıkardığı gibi uzaktan eğitim modeli de öğrenciler bazında eşitsizlikleri ortaya koymuştur. Uygulamaya konan uzaktan eğitim 
modeli için gerekli olan teknolojik aygitlar, araçlar ile yeterli maddi olanaklara ve ev içinde uygun koşullara sahip olan öğrencilerle sahip olmayan öğrenciler arasında mevcut olan eşitsiz koşulların yarattı̆̆ handikaplı durumlara koşut bir biçimde, kadın öğrencilerle erkek öğrencilerin bu modelin hayata geçirilmesi sırasında eşit koşullar altında uzaktan eğitimden istifade edememe olasılı̆̆ını da göz ardı etmemek gerekir. Bunun sebeplerinden birisi olarak da, UNICEF' in 2020'de raporladığ 1 son 25 yılın verilerine göre, "ergen kızlar[ın] erkek akranlarına kıyasla ev işlerine ciddi ölçüde daha fazla saat ayırmakta" olmalarıdır (UNICEF, UN Women \& Plan International, 2020, s. 16). Bundan dolayı da, genel olarak, pandemi sürecinde eğitime uzaktan devam etme gibi alınan önlemlerin sonucunda bu süreç sırasında ve sonrasında kadın öğrencilerin eğitimlerine yeterince çaba gösterememe ve eğitimlerine ara verme ya da eğitimlerini yarıda bırakma oranlarının yükseleceği yönünde bir kaygı baş göstermiştir. Diğer bir taraftan, "[o]kulların kapanması kız çocuklarının sadece evde daha fazla ev işi yapması anlamına gelmemekte, aynı zamanda milyonlarca kız çocuğunun eğitimlerini tamamlamadan önce okuldan ayrılmasına neden olabilmektedir. Özellikle yoksulluk içinde yaşayan, engeli olan veya kırsal, ücra bölgelerde yaşayan kızlar için bu, daha fazla söz konusudur" (BM, 2020b, s. 14).

Bu durum ise, sadece kadın öğrencilerin ve/veya ailelerinin, çevrelerinin geleceği ve refahı için değil aynı zamanda toplumların ve ülkelerin geleceği ve refahı için de önemli bir risk oluşturmaktadır. Genç kadınlara eğitim bir diploma, bir meslek, bir gelir kaynağı sağladığı gibi aynı zamanda daha bilinçli, daha eleştirel ve zihnen daha gelişmiş bir birey olmalarını da sağlamaktadır. Fakat pandemi sürecinde ortaya çıkan olağanüstü koşullar altında hem ev içi iş yükünü hem salgının yarattı̆̆ psikolojik ve fizyolojik sorunları hem de akademik gelişimlerini bir arada yürütmek kadın öğrenciler için hayli zorlayıcı da olmuştur. Keza, pandemi sürecinde, -eğitimin iki ana aktörü olan öğrenciler ve eğitimciler olmak üzere- her iki taraf için de yeterli imkânlar ve uygun koşullar oluşturulmadan acilen fiiliyata geçirilen uzaktan eğitim modelinin işlerliği, işlevselliği, etkinliği ve verimliliği de ilk hayata geçirilmeye başlandığı günden beri hayli tartışlan da bir konu olmuştur. Orta Doğu Teknik Üniversitesi Eğitim Bilimleri Bölümü'nden Dr. Serap Emil'in (2020) de ifade ettiği gibi, uzaktan eğitim olarak kabul edilen bu eğitim modeli esasında 
bir 'acil durum uzaktan eğitim' modelidir ve normal şartlarda nitelikli ve donanımlı bir biçimde yürütülen uzaktan eğitim modelinden de uzaktır. Emil'e (2020) göre:

Martın son haftasıly birlikte vermekte olduğumuz dersleri çeorimiçi ortama aktararak uygulamaya başladığımız süreç 'uzaktan eğitim' değil 'acil durum uzaktan öğretimi' (emergency remote teaching) idi. [...] Elbette Türkiye yükseköğretiminde uzaktan eğitim veren başarıl kurumlarımı mevcut, ancak bu acil durum uzaktan öğretimi çoğumuz için yeni ve bilinmezliklerle dolu bir labirent gibiydi. Öğrenciler tarafindan dile getirildiği üzere onlar için bitmeyen ödevler, bizler için gecesi gündüzü ve hafta sonuyla bitmeyen mesailer, bölüm düzeyinde alınması gereken kararlar ve bir yandan da korona korkusu olarak hayatlarımıza girdi. [...] Uzaktan eğitim uzun yillardır araştırmalara konu olan, uzaktan öğretim ve öğrenmeyi içinde barmdiran bir kavram. Burada öğrenciler açısından gerekli olan etkili öğrenme deneyimi dikkatli bir şekilde tasarlanmış bir öğretim deseni gerektiriyor. Acil durum uzaktan öğretiminde ise bu şekilde tasarlanmış bir öğretim ya da öğrenme sürecinden söz etmek mümkün değil. Kriz dönemlerinde öğretime erişimi sağlamak amactyla yüz yüze yapılması yerine uzaktan öğretim olanakları aracılığıly gerçekleştirilmesi demek, ve bizlerin pandemi sonucu yaptığımı öğretimin tam da bu olduğınu düşünüyorum. Örneğin, yüz yüze tasarladığımız dersleri, kısa sunumlarla ya da videolarla, okuma materyali ve ödevlerle çeorimiçi ortamda sunmak. Uzaktan eğitim ise iyi planlanmış öğretim ve öğrenme süreçleri demek. Yani öğretimi tasarlarken yöntem, eğitimin hızl, öğrenci-ögretim üyesi oranlar, ögrretim üyesinin ve öğrencinin rolü, pedagojisi, geribildirim sistemi ve değerlendirme gibi boyutlarm her birinin göz önünde bulundurulması gerekiyor.

Bir diğer yandan, bu süreç bağlamında, uzaktan eğitimin daha kırılgan tarafı olan üniversite öğrencilerinin içinde bulunduğu koşulların anlaşılıp ona uygun bir uzaktan eğitim modelinin hayata geçirilmeye çalışılması yerine, bu türden bir eğitim modeline uygun bir zeminin olup olmamasına çok da bakılmadan hızla alınan kararlarla öğrencilerin bu modele uygun olmayan koşulları ve imkânları üzerinden bir eğitim süreci işletilmeye çalışıldığ görülmektedir. Bu nedenle, bu olgunun mevcudiyetini ve sinırlılıklarını ölçmek için, kadın öğrencilerin uzaktan ve online olarak yapılan eğitim-öğretim faaliyeti için evlerinde gerekli teknolojik imkânların mevcudiyeti sorulmuştur. Şekil 1'de görüleceği üzere, 33 katılımcıdan 24'ünün evinde internet olanağı varken, $9^{\prime}$ u evinde böyle bir imkânın olmadığını belirtmiştir. Bunun ya- 
nında, Şekil 2' de görüleceği gibi, 17 öğrenci evinde bilgisayar olduğunu belirtirken, 16'si bilgisayarın olmadığını ifade etmiştir. Bu yanıtların oranları nedeniyle, bu bağlamda uzaktan eğitimi hangi araç üzerinden yürüttükleri sorulmuştur. Şekil 3'te görüleceği üzere, uzaktan eğitim sürecinde 21 öğrenci telefonunu kullanırken, 10'u kendi bilgisayarını, 6'sı bir arkadaşının, bir akrabasının ya da yakının bilgisayarını ve 4 'ü de evdeki ortak bilgisayarı kullanmıştır. Bu verilerden de anlaşlacağı gibi, öğrenciler ağırlıklı olarak akıllı telefonları üzerinden uzaktan eğitim sürecine katılmış ve bu türden telefonların bir bilgisayar gibi etkin ve işlevsel kullanılma imkânının düşük olması nedeniyle bu durum öğrencilerin eğitimlerini uzaktan da olsa nitelikli bir biçimde sürdürmelerini engellemiştir. Uzaktan eğitimin yürütüldüğü yaklaşık 3 aylık bir süre içerisinde, derslerin, okumaların, sınavların ve ödevlerin telefon üzerinden yapılmaya çalışılması, bu sürecinin öğrenciler için hayli zorlu geçtiğini de göstermektedir. Bunların yanında, TÜiK'in 2019 tarihli Hanehalkı Bilişim Teknolojileri Kullanım Araştırması verilerine göre de, Türkiye'de hanelerin \% 88,3'ünde evden internete ulaşım mümkünken, hanelerde masaüstü bilgisayarın bulunma oranı \%17,6, taşınabilir bilgisayarın bulunma oranı $\% 37,9$, tabletin bulunma oranı \%26,7; cep telefonunun bulunma oranı ise \%98,7 idir (Göğüş-Tan, 2020; TÜİK, 2019). Diğer taraftan Mine Göğüş-Tan'ın (2020) da ifade ettiği gibi, "[a]ncak hanelerde dijital teknoloji ve internetin bulunması, bu teknolojileri kullanmak için gerekli becerilerin gelişmesindeki eşitsizlikleri kapatm[ası]" mümkün görünmemektedir.

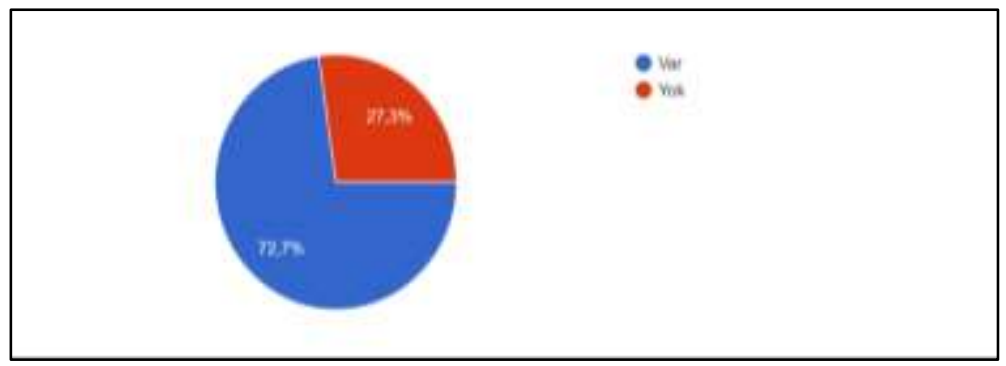

Şekil 1. Evdeki İnternet Olanağı 


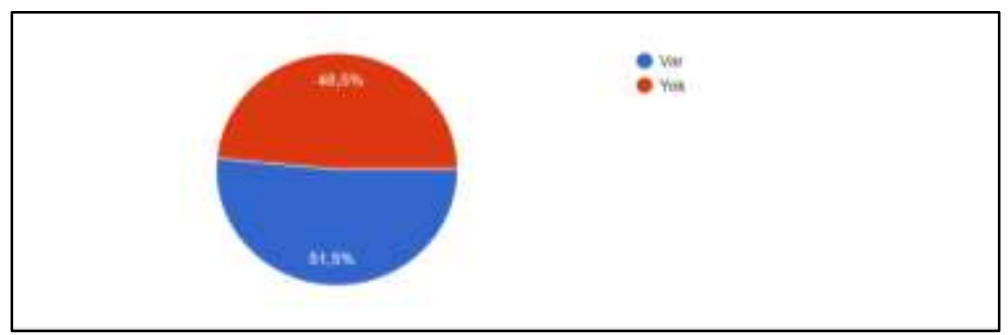

Şekil 2. Evdeki Bilgisayar Olană̆ı

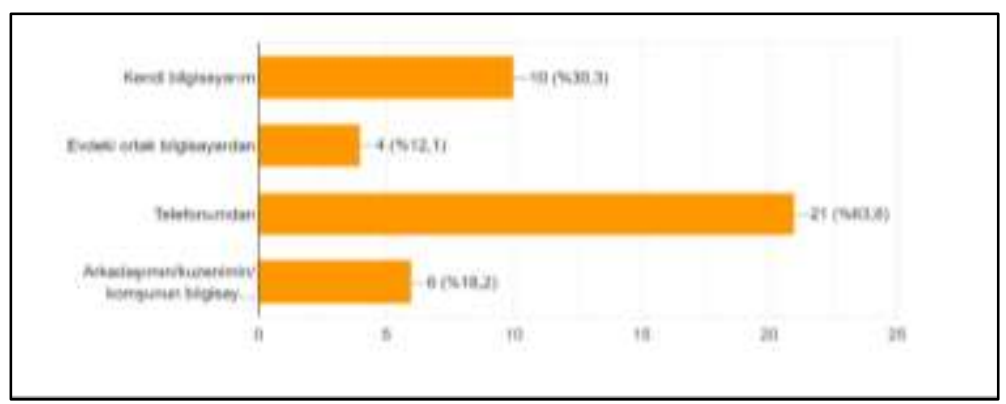

Şekil 3. Uzaktan Eğitimin Yürütülmesi İçin Kullanılan Araç

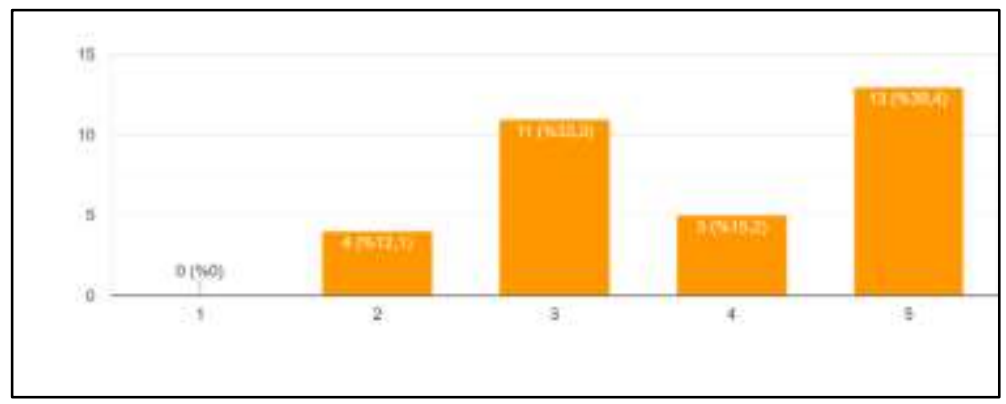

Şekil 4. Uzaktan Ĕ̆itimin Katkısı

Bu nedenle, katılım gösteren kadın öğrencilere, pandemi sürecinde uygulanan uzaktan eğitim modelinin akademik manada kendilerine önemli bir fayda sağlayıp sağlamadığına dair görüşleri sorulmuştur ve gelecek yanıtlar için de oransal ölçeklendirme kullanılmıştır. Şekil 4' te görüleceği üzere, uzaktan eğitimin kendilerine katkısını değerlendiren katılımcılardan 13'ü güçlü bir "hayır", 5'i çekinceli bir "hayır", 4'ü çekinceli bir "evet" derken, 11'i nötr cevap vermiştir fakat hiçbir katılımcı bu katkıyı olumlayan güçlü bir "evet" 
seçeneğini tercih etmemiştir. Bu da göstermektedir ki kadın öğrenciler pandemi sürecinde yürütülen uzaktan eğitim modelinden öğrenimleri için bir fayda sağladığını düşünmemektedirler. Diğer taraftan, öğrenimleri açısından, pandemi sürecinde uygulanan uzaktan eğitimi modeli ile yüz yüze eğitimi karşılaştırmaları istenmiş ve gelecek günlerde gereksinim dâhilinde hangisini tercih edebilecekleri sorulmuştur. Şekil 5'te görüleceği üzere, bu bağlamda 30 öğrenci yüz yüze eğitimi tercih ettiğini/edeceğini belirtirken, 3'ü uzaktan eğitim modelini tercih etmiştir. Bu veriler pandemi sürecinde hayata geçirilen uzaktan eğitim modeli konusunda çalışmaya katılan öğrencilerin hayli olumsuz bir izlenimi olduğunu ortaya koymaktadır.

Bunların yanısıra, katılımcılara uzaktan eğitim sürecinde yaşadıkları zorluklar da sorulmuştur. Gelen yanıtların geneline yansıyan ise internet bağlantısı ile ilgili sıkıntılar, bilgisayar ve telefon kullanımına dair sorunlar, derslerin işlenmesi sırasında verilen okumaların, materyallerin, vb. ders yükünün biraz fazla olması, öğretim elemanlarının öğrencilerin mevcut koşullarını umursamayan, göz ardı eden ya da yok sayan bir tutum sergilemeleri, derslere hazırlanırken ya da ödevleri yaparken kaynaklara ulaşmada sıkıntı yaşamaları, sınavlar sırasında sınav süresinin azlığı ya da internet bağlantısının kötü olması nedeniyle sınavlarda başarılı olamamaları ve bazı sınavlarda kopya çekildiğine dair bir kanının olması gibi etmenlerin yanısıra ev içi iş yükü ve pandeminin yol açtığı psikolojik baskı ve tüm bunların yarattığı fizyolojik sıkıntılar gibi zorlukları saymak mümkündür. Öğrencilerin bu süreçte yaşadıkları diğer sorunları ise; ev halkının anlayışsızlığı, her türden maddimanevi olanak kısıtlılığı, evdeki işlerin sıkıştırması, ailenin sürekli yardım beklentisi gibi başlıklar altında toplamak mümkündür. Öğrenci kadınların hem uzaktan eğitimde başarılı olmak için hem de kardeşlerinin derslerine yardım etmek, çeşitli ev işlerini yapmak ve aileye maddi-manevi destek olmak gibi yükümlülüklerle uğraştıkları görülmektedir:

"Köyde yaşadığımdan dolayı internet sorunu yaşadım ve ailem her zaman ders çalışma konusunda anlayış gösteremedi. Köy ve ev işlerinden dolayı ders çalışmakta zorlandım. Evde de iki tane küçük çocuk olması işimi daha çok zorlaştırdr." (Y6)

"Bulunduğum köyden ilçe merkezine kırtasiyeye ulaşmak üzere, birçok kez gidip gelmeler yaşadım." (Y14) 


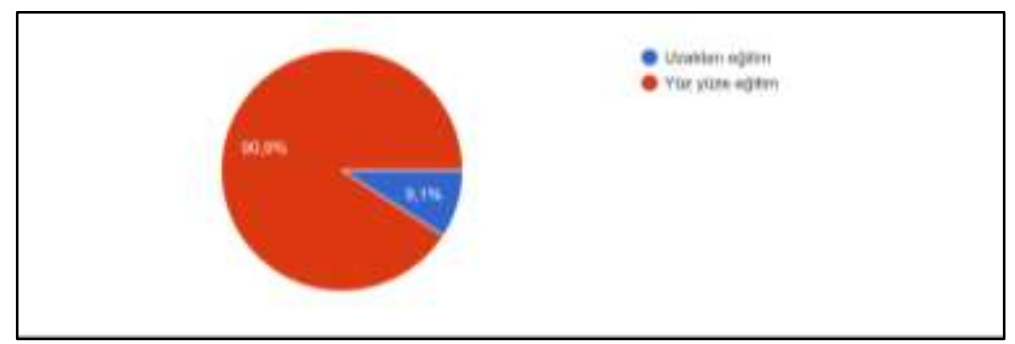

Şekil 5: Uzaktan Ĕ̆itim Mi? Yüz Yüze Ĕ̆itim Mi?

“Ortaokul öğrencisi olan kardeşimin dersleri ile benim sınavımın çakıştığı zamanlar oldu ama kardeşim videolarn ileri veya geri alarak halletmeye çalışt. Kardeşimin de çok fazla ödevi oluyordu, benim de öyle. Bu yüzden evde bazen bilgisayar yüzünden tartı̧̧malar çıkıyordu ve bu tartışma üzerine bilgisayarı alsam da ödev yapmaya başladığımda kafamı toparlayıp ödev yapamıyordum, odaklanamıyordum. Ev ortamında tabi ki zaman zaman anne baba tartışmaları da olabiliyor ama ben gün geçtikçe bu konuda zorlandım, yani üzüldüm ve okuduğum şeyleri anlamamaya başladım. Evde yazıcıma kadar ihtiyacım olan her şey olmasina rağmen 80 gündür bir evin içinde olmak ve dışar çıkmamak psikolojimi gerçekten kötü yönde etkiledi. Bazı hocalarımızın bu zor günlerde bizim yanımızda olacaklarından şüphe etmememize rağmen tam tersi bir durumla karşılaştık." (Y18)

"Evdeki tek kız ve en büyük çocuk olmamdan dolayı ev içi sorumluluklarım çok fazlaydı. O yüzden derslere okulda olduğu kadar fazla vakit veremedim." (Y19)

"Bu süreçte maddi imkânsızliklar (bilgisayar, internet vs.) yönünden bir zorluk yaşamasam da, ilk defa uzaktan eğitimi tecrübe etme ve bunu gönüllü olarak yapmama nedenlerinden dolayı bazı psikolojik bazı etkileri oldu. Bunun yanısıra evde uzun süre standart bir yaşam sürmek algılama hızımı düşürdü. Bu durumu evdekiler de yaşadığı için ara sıra anlaşmazlıklar ve tartışmalar oldu. Bunlarda doğal olarak moral bozukluğu yaşattı. Bir süre abimle tek kalmak zorunda oldum. Kendisi her gün yemeği yapan olsa da genel anlamda anlayışl biri olsa da bazen hiç olmadık zamanda, ödev yetiştirmem gerekirken bir şey rica etmesi halinde "sonra" cevabını vermemden pek hoşnut kalmıyordu. Bu durum ise üzerimde psikolojik bir baskı yaratıyordu. Bunun haricinde okul yönünden uzaktan eğitim değerlendirilmesinde ise çoğu hocamı anlayışl ve iletişime açı bir tutum sergilerken bazı hocalarımızm bunun aksine davranması zaman zaman karantina sürecine tuz bastı." (Y21) 
"Internet ve bilgisayar olanağı olmadığından borca girip almak durumunda kaldik." (Y26)

"Çıktı alma konusunda zorlandım. Bilgisayar var ama bozuk. Dayımdan ödünç aldım. Çalş̧ıorum ayn zamanda. Yorgun yorgun gelip ödevlerle ilgilenmeye çalışıyorum. Haftalı ödevlerimiz oluyor. Okuldayken daha az okuma yapryordum. Eminim uzaktayız ve hocalarımız da bizi düşünerek atıyor tabi ki kaynakları. Daha iyi anlamak için atılan bütün kaynakları okuyorum ve çalışınca da zor oluyor haliyle. Bazen hocalarımız da sanki bizi anlamıyorlarmış gibi düşündüğümüz bile oldu açıkçası... Ama her şeye rağmen bütün derslerinin neredeyse tüm konuları kavradım diyebilirim." (Y27)

"Bilgisayarım olmadığı için ödevler konusunda yeterli araştırmalar yapamadım. Köyde olduğum için ve santral olmadığı için evimizdeki modem bağlantısı hep sorunluydu. Süreli olan sinavlarda bile elektrik kesintisinden dolayı internet kesildi ve başka internet olanağım olmadığı için sinavımı yapamadım kaldım. Köyde her gün saatlerce elektrik kesintisi yaşryoruz ve sinavda da ya yine tekrarlanirsa korkusuyla başarılı olamıyorum. Kalabalık olduğumuz için ve odaklanmada sıkıntı yaşadığım için gürültülerden etkilenip ders çalışma imkânım nerdeyse imkânsız. Sağlık sorunları çektiğim için hem fiziksel hem ruhsal bu süreçte bayağı bir zorlandım. En fazla üzüldüğüm konu ise tüm hocalarımızın anlayıssıı olması, kimisi işlemediği halde sorular sorup sıkıntıya soktu. Kimisi çok geç kaynak attı. Kimisi haftalık en az 300 sayfa attı. Bir şeyleri öğretmek kesinlikle bu şekilde olmaz. Ö̆̆renci olduğumuz için tüm hocalar evimizin dört dörtlük olduğunu boş oturduğumuzu ve sadece çalışmamı gerektiğini düşünüyor sanırm fakat durum böyle değil. Evinde masası olmayan arkadaşlarım bile var. Benim gibi evi kalabalık olan, internet, bilgisayar sıkıntısı çeken, odak sorunu yaşayan, sağllk sorunları olan öğrenciler var." (Y30)

Kadın öğrencilerin pandemi sürecinde uygulanan uzaktan eğitime yönelik olumsuz görüşlerinin önemli dayanaklarından biri uzaktan eğitim süresince dersler, ödevler ve sinavlar için yeterince zaman ve emek verme olanaklarına sahip olup olmamaları ile ilgili olduğu görülmüştür. Aşağıda verilen öğrencilerin kendi anlatılarında da görüleceği gibi, öğrenciler ağırlıklı olarak yeterince zaman ve emek vermediklerini/veremediklerini ya da vermeye çalıştıklarını belirtip, bunun sebebi olarak da kendileri ile ilgili ya da çevreden/dışarıdan gelen çeşitli faktörleri saymaktadırlar. Kendileri ile ilgili faktörler karantina koşullarının neden olduğu psikolojik ve fizyolojik sıkıntılar, uzaktan eğitim konusunda hazırlıksız ve deneyimsiz olmaları, evin rehavetine kapılmaları gibi etmenler iken, dışarı kaynaklı faktörler genel olarak ders 
yükünün yoğunluğu, öğretim elemanlarının umursamazlığı ve dersler, ödevler, sınavlar hususunda katılığı, ev içi ve dışı iş yükünün fazlalığı, aileleri ile olan ilişkilerinin bu süreçteki yoğunluğu, doğal afetler, teknolojik sorunlar gibi sıkıntılardır. Yine de, her şeye rağmen yeterince zaman ve emek verdiğini belirtenler de vardır:

"Yeterince zaman veremedim. Çünkü karantina süreci olduğu için herkes doğal olarak evde olduğu için ev işlerinden bazen derse oturmaya firsat bulamıyordum. Yorgun geçtiği için kendimi derse veremediğim zamanlarım çok oldu." (Y2)

"Bir yere kadar zaman iyi zaman verdim. Fakat ziraat mevsiminin açllmastyla bu zamanı biraz kıstım." (Y4)

"Yeterince zaman veremedim çünkü köyde yaşadığım için ev ve köy işleri ve ailemin davranış biçimleri etkili oldu." (Y6)

"Yeterince zaman veremedim. Ev işleriyle vakit geçirdim. Çünkü annemin bir yıl önce vefat etmiş olması dengeleri değiş̧tirdi. Herkes daha fazla ilgilenmek zorunda kalıyor evle. Ayrıca büyük şehirde yaşadığımı için ayrıca bir risk vard. Kaygılar da oldukça etkiledi herkesi." (Y7)

"Emek vermek konusunda yeterince emek verdiğimi düşünüyorum fakat bu konuda pandemi koşullarında ve internet erişiminde yetersizlik yaşamamıza rağmen bazı öğretmenlerimizin bunlan göz önünde bulundurmadığına inanıyorum. Ben diğer arkadaşlarıma oranla daha rahat ve elverişli bir ortamda yaşıyorum, fakat herkes buna sahip değil. Bu süreçte en çok ihtiyacımı olan hoşgörüydü ve unutulmaması gereken herkes herkesle eşit şartlar ve koşulda değil." (Y8)

"Yeterince değil. Neredeyse hiç zaman veremedim. Babaannem, dedem ve kardeşlerim ile yaşıyorum ve işler çok engel oldu. Aynuca bağ bahçe işleri de almış başın gitmiş vallaha. İş yapmasam vicdanım sızlıyor, iş yapsam dersler bakıyor. O yüzden bu süreçte sadece ödevler ile ilgilendim." (Y19)

"Kısmen diyebilirim. Eve aniden gelme sürecinde ben kadar ailem de şaşkındı ve herkesin kurulu düzeni vardı. Kendi masamı, odamı kendim kurdum diyebilirim. Kendime bir alan açtım mağdur olmamak için. Tabi bu kolay olmad." (Y22)

"Deprem + karantina süreci." (Y23)

Bunun yanında, çalışmaya katılım gösteren kadın öğrencilerin pandemi sürecinde evlerinde yükümlü oldukları işler Şekil 6'da görüldüğü gibi şunlardır: Yemek, bulaşık, çamaşır, ev temizliği, oda temizliği, küçük kardeş(ler)/çocuk(lar)/bebek(ler), yaşlı ve/veya hasta/engelli aile üyelerinin bakımı, bahçe, tarla, hayvanlar, ahır işleri gibi yüklendikleri ve/veya ailenin diğer üyeleri ile iş yükünü paylaştıkları ev içi ve dışı işlerdir. Ayrıca, yabancı 
öğrenci olduğu için bu süreçte yurtdışına çıkamadığı için evlerine dönemeyen ve öğrenim gördükleri yerde kalan öğrencilerin mevcudiyeti de ayrı bir tablo oluşturmaktadır. Pandemi öncesinde yurtta ya da ev arkadaşları ile paylaştıkları evlerde kalan bu öğrenciler, bu dönemde sorumlu oldukları derslerin, ödevlerin ve sınavların yanısıra, ailelerinden uzakta karantina koşulları altında kalakaldıkları evin tüm iş yükünü tek başlarına yürütmeye çalışmışlardır.

Çalışmaya katılan kadın öğrencilerden, karantina koşulları altında keyifle yaptıkları aktiviteler ve uğraşlar konusunda ise; ağırlıklı olarak müzik dinlemek, film/çizgi film izlemek, resim yapmak, kitap okumak, yeğenle vakit geçirmek, odayı ya da evdeki eşyaları yeniden dizayn etmek, puzzle yapmak, el sanatları ile uğraşmak, dinlenmek ve uyumak gibi kişisel yanıtlar gelmiştir. Bunların yanısıra yemek yapmak, pasta yapmak, yeni tarifleri denemek, evi temizlemek ve hayvanlarla, bahçeyle, toprakla zaman geçirmek gibi esasen ev içi ve dışı iş tanımına girecek aktiviteler ve uğraşlar da sayılmıştır. En ilginci ise ders çalışmak, ödev yapmak, makale ve ders kitaplarını okumak gibi aktivitelerin de katılımcılar tarafından keyifle yaptıkları aktiviteler ve uğraşlar bağlamında ifade edilmiş olmasıdır. Bu noktanın altının çizilmesindeki esas sebep ise 7/24 evde vakit geçirmek zorunda kalan öğrencilerin bu dönemde dersleri ve eviçi iş yükü haricinde zamanlarını nasıl geçirdikleri aynı zamanda onların pandemi sürecinde gündelik yaşamları hakkında ve uzaktan eğitimden kalan zamanı kullanma biçimleri hakkında da bir ipucu da vermektedir. Sonuçta, boş zamanlarını geçirdikleri uğraşları arasında, kendilerini ve varoluşlarını ifade edebilecekleri başka türden etkinlikler yerine, ev içi ve dışı iş yükü ile uzaktan yürütmeye çalıştıkları öğrenimlerine dair faaliyetlerin olması ise kadın öğrencilerin hem pandemi dönemi için hem de genel anlamda gündelik yaşam hakkında önemli bir noktayı işaret de etmektedir. 


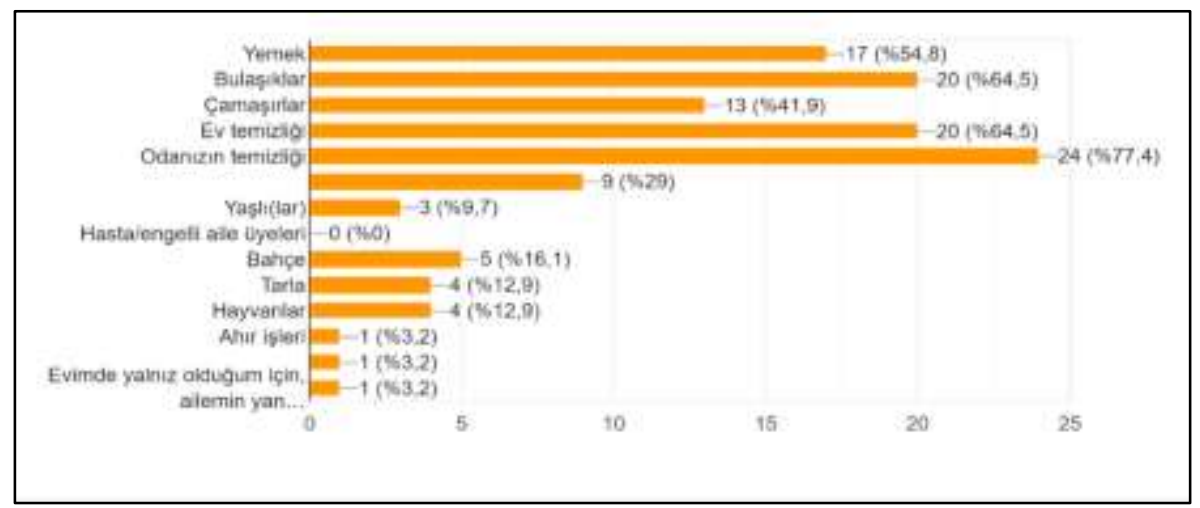

Şekil 6. Pandemi Sürecinde Evde Yaptıkları İşler

\section{Sonuç}

COVID-19 pandemisinin ortaya çıtığı ve tüm dünyaya yayılması sonrası su yüzüne çlkan en bariz olgularından birisi varolan toplumsal eşitsizliklerin son 50 yılda ne kadar derinleştiğidir. Özellikle de son 40 yıldır tüm dünya sathında uygulanmakta olan neoliberal politikalarla özelleştirilip bir kamu hizmeti olmaktan çıkarıp özel sektörün eline teslim edilen sağlıktan eğitime, bakım hizmetinden sosyal güvenliğe gibi temel kamu hizmetlerine ulaşımda yaşanan sorunlar toplumsal sınıflar arasındaki uçurumu da gözler önüne sermiştir (Saad-Filho, 2020). Pandemiden ve yarattı̆̆ koşullardan toplumları oluşturan her bir birey ve grup farklı etkilenmiştir ve her bir birey taşıdığ 1 kimliklerin madunluk seviyesine göre pandemi sürecinde ortaya çıkan eşitsizlikten ve ayrımclıktan payına düşeni almıştır. Bu süreçte en çok etkilenen kesimler başta kadınlar olmak üzere gençler, çocuklar, yaşlılar, engelliler, yoksullar, vb. gibi toplumsal gruplar olmuştur. Mesela, "Türkiye' de çalışan kadınların \%42,2'si temizlik, çocuk bakımı gibi güvencesiz işlerde" çalışmakta ve pandemi süreci gibi bir kriz anında ilk işini kaybedenler ve zaten güvencesiz çalıştıkları için herhangi bir biçimde sosyal güvenlik mekanizmalarından yararlanamayanlar bu kadınlar olmaktadır (BM, 2020a).

Nitekim, pandemi öncesinde hem ücretli hem de ücretsiz bakım emeğinin baş aktörü olan kadınların çoğu, pandemi sonrası dönemde bakım emeğinin ağırlıklı olarak ev alanına çekilmesiyle bu sefer işsiz ve güvencesiz bir şekilde evde karantina koşulları dolayısıyla katlanarak artmış ev içi iş yükü ve bakım 
hizmetlerini ücretsiz, karşılıksız olarak vermeye devam etmektedirler. Kadınların bir kısmı ise işlerini, mesleklerini, eğitimlerini evlerinden sürdürme durumundadır fakat aynı durumdaki bir erkeğe göre kat be kat daha fazla ev işi yaptığı ve bakım hizmeti verdiği de açıtır. Tüm bu tabloya ek olarak, kadınların hanede karşılaştıkları ev içi iş yükü sorunlarının yanında, ev içi şiddetin hızla artış göstermesi de kadınlar açısından karantina koşullarının yarattı̆ı en önemli problemlerin başını çekmektedir. Karantina koşulları nedeniyle, ev içinde aile bireylerinin daha çok bir arada olması, ortaya çıkan ekonomik ve toplumsal sıkıntıların aile içindeki huzursuzlukların artısıın tetiklemesi gibi sebepler ev içi şiddetin ve cinsel istismarın ortaya çıkmasına ve artış göstermesine yol açabilmektedir (BM, 2020a).

Bunun yanısıra, karantina koşulları nedeniyle uzaktan verilmeye başlanan örgün eğitim içinde yer alan kız çocukları ve genç kadınlar ev içinde ev içi iş yükünden karşı karşıya kaldıkları aile içi şiddete ve cinsel istismara kadar birçok zorlukla bir arada olarak eğitimlerine devam etmeye de çalışmaktadırlar. UNESCO'nun (2020) önceki salgin deneyimlerinden elde ettiği veriler ve bilgiler ışığında ortaya koyduğu gibi, muhtemelen, bu zorlu koşullar altında yaşayan kız çocuklarının ve genç kadınların bir kısmı gelecek günlerde eğitimlerini yarıda bırakmak zorunda kalacaklar, devam edenler ise eğitimlerine yeterince ilgiyi ve özeni gösteremedikleri için eğitimlerine devam etmede ciddi sıkıntılar yaşayacaklar ve eğitimlerini başarılı bir biçimde sürdüremeyeceklerdir. Bu ise hem kız çocuklarının ve genç kadınların yaşamları için hem de toplumun ve ülkenin geleceği için büyük bir tehlike olarak ortaya çıkmaktadır. Bu sebeple de, bu çalışmada, kadın öğrencilerin hem pandemi hem de uzaktan eğitim sürecinde yaşadıkları sıkıntılar betimlenmeye çalışılmış ve böylece kadınları gelecek günlerde bekleyen risklerden biri olarak pandemi sonrası dönemde ortaya çıacak bazı yeni koşullar nedeniyle genç kadınların eğitimlerini devam ettirmede yaşayacakları muhtemel sorunlar ve bu sorunların onların gündelik yaşamlarındaki muhtemel tezahürleri ortaya konmak istenmiştir.

Çalışmanın geneli bakıldığınca görülecektir; kadın üniversite öğrencilerinin pandemi nedeniyle hayata geçirilen karantina koşulları ve bu dönemde uygulamaya konan uzaktan eğitim modelinin gündelik yaşamlarında onlara yaşattığı iki ana zorluk ortaya çıkmıştır. İlki öğrencilerin gündelik yaşamlarında kendileri ile ilgili sıkıntılar olarak pandemi sürecinin yarattığı psikolo- 
jik ve fizyolojik sorunlar iken, ikincisi dışarıdan gelen sıkıntılar olarak eğitimlerini uzaktan sürdürmek için gerekli olan teknolojik aygıt ve araçlarla yaşadıkları sorunlar, ev içi ve dışı iş yükü ile dersler, sınavlar, ödevler hususunda deneyimledikleri zorluklardır. Tüm bu sıkıntılar sonuçta kadın öğrencilerin hem gündelik yaşam kalitesini hem de akademik gelişimlerini ciddi biçimde etkilemiştir.

Lakin, diğer taraftan, 'yeni' normal olarak adlandırılan pandemi sonrası dönemde ortaya çıkacak şartlar kadınlar için hayli zorlayıcı olacak gibi durmaktadır. Bu süreçte artış gösterecek olan ekonomik ve toplumsal krizler nedeniyle artan işsizlik bir yandan istihdam piyasasındaki rekabeti körüklerken diğer yandan güvencesiz ve esnek çalı̧̧ma koşullarını da yükseltecektir. Böylesine bir ahval içinde, bir anlamda emek piyasalarının zayıf zinciri olan kadınlar, hem eğitimden bir biçimde uzak kalmak hem de artan ev içi iş yükünü ve ev içi-dışı bakım hizmetini üstlenmek zorunda kalmaları nedeniyle daha esnek, daha güvencesiz, daha çok şiddetin yer aldığı bir yaşam bekleme riskiyle karşı karşıyalardır. Nitekim, Agamben' in (2020b) belirttiği gibi, esas sorun yalnızca şimdiye kadar olanlar değil bundan sonra olacaklardır:

Salgımın net bir şekilde ortaya çımasına neden olan ve ilkinden daha az rahatsız edici olan diğer şey, hükümetlerin bizi bir süredir alıştırdığı 'istisna durumların' normal koşullar haline gelmesidir. Geçmişte daha ciddi salginlar oldu ama hiç kimse bu nedenle şimdiki gibi acil bir durum ilan etmeyi düşünmedi. Bu durum hareket etmemizi bile engelliyor. Insanlar uzun yıllar süren kriz ve aciliyet durumlarmda yaşamayı o kadar alşskanlık haline getirdiler ki hayatlarmın tamamen biyolojik bir duruma indirgendiğini ve durumun sadece sosyal ve politik değil aynı zamanda insani ve duygusal boyutu olduğunu fark etmediler. Uzun yıllar olağanüstü durumda yaşayan bir toplum özgür bir toplum olamaz. Aslında 'güvenlik nedenleri' denilerek özgürlü̈̆̈̈ feda edilen ve bu nedenle kendisini yıllarca süren korku ve güvensizlik durumunda yaşamaya mahkûm eden bir toplumda yaşıyoruz. [...] Acil durum önlemleri bizi sokağa çıkma yasă̆ı koşullarında yaşamaya zorunlu kılıyor. Fakat görünmez bir düşmana sahip olan ve her insanda gizlenebilen bir savaş, en saçma savaştır. Gerçekte ise bu bir iç savaştır. Düşman dışarıda değil, içimizdedir. Endişe verici olan sadece şimdi fazla olan şeyler değil, bundan sonra gelecek olan şeylerdir.

Bu nedenle, yapılacak olanların başında ise, kadınların ve kadın hareketlerinin pandemi sonrası süreçte toplumsal cinsiyet eşitsizliği nezdinde ortaya çıkabilecek muhtemel risklere karşı devlet organlarının ve sivil toplum örgütlerinin gerekli önlemleri alması hususunda çalışmalar yürütmesinin yanısıra, 
bu önlemlerin gündelik hayatta etkin bir biçimde gerçekleştirilmesi aşamasında kadınların hem hane içinde hem de kamusal alanda ciddi bir biraradalık yaratma ve bunu fiiliyata dökme mücadelesini yürütmeleri gelmektedir. Diğer taraftan, genel tablonun içindeki bazı özel motiflere daha yakından bakmak gerekirse, bu çalışmada ortaya konduğu gibi, sosyo-ekonomik ve sosyo-kültürel olarak kısıtlı ve yetersiz koşullar altında yaşayan genç kadınların gelecekleri için oldukça önemli bir yer tutan yükseköğrenimlerini başarı ve yetkinlikle tamamlamalarının sağlanması, hem kadınların bireysel yaşamları bazından hem de toplumun genelin bazında kadınların konumlarının iyileştirilmesi ve toplumsal cinsiyet eşitsizliğine karşı verilen mücadeleyi destekleyici bir nitelik taşımaktadır. Bu çalışmanın da ele aldığı gibi, pandemi sürecinde bu amacın önünde yer alan en ciddi engel ise genç kadınların ev içi ve dışı iş yükünü üstlenmek zorunda kalmalarının yanısıra maddi ve manevi zorluklar altında bu süreçte hayata geçirilen uzaktan eğitim modeli çerçevesinde sorumlu oldukları öğrenimlerini devam ettirmede yaşadıkları sorunlardır. Bundan dolayı, toplumsal hayatın önemli birer neferi olan genç kadınların hem şimdiki hem de gelecekteki yaşamlarını inşa ederken önemli bir kırılma anını yaşadıkları bu pandemi döneminde geçirdikleri sürecin yaşamları için kritik bir dönüm noktası olma ihtimali yüksektir. Netice itibariyle de, hem bireyler nezdinde hem de toplum nezdinde bu sürecin emin bir biçimde atlatılabilmesi için başta Yükseköğretim Kurumu (YÖK) olmak üzere devletin yetkili mercileri, başta öğretim elemanları olmak üzere üniversitelerin akademik ve idari kadroları ve genç kadınların ailelerine çok önemli görevler düşmektedir ve bu görevlerin gereğince yerine getirilmesi sadece bugün ortaya çıkan değil aynı zamanda yarın da ortaya çıkması muhtemel değişim ve dönüşümler için gerekli adımların atılmasının girizgâhı olacağı da muhakkaktır. 


\section{EXTENDED ABSTRACT}

\section{Effects of the Pandemic Process on the Female University Students and Problems They Lived with the Implemented Distance Education Model}

Emek Yıldırım Şahin

Artvin Çoruh University

The public life has been limited as a part of pandemic counter measures announced right after new kind of coronavirus COVID-19 first emerging in December of 2019 starts to spread all over the world. In Turkey, since 16 March, beside schools being in the first place, many public and private sectors terminate their activities from time to time, quarantines, lockdowns and travel restrictions are declared, and lockdowns for people under the age of 20 and over the age of 65 are applied except certain time of periods. Although a normalization process was started to actualize with loosening measures by the end of May, the number of cases has begun to increase and the measures are started to re-actualize again by the autumn. Initially, the pandemic changes the daily life of people completely throughout the world was stated as a fact that equalizes all humanity but in time it was realized that it has not such an attribute. The problems, difficulties of subordinate segments particularly such as immigrants, refugees, women, poor people, etc. who encountered with discrimination, inequalities in various ways before the pandemic have been arisen much more by the pandemic process. It is evident that especially daily life of women becomes labor-intensive further after the pandemic. Domestic work load of women has been increased substantially with many extra works such as paying more attention for domestic and non-domestic hygiene, looking after elders, handicapped family members, patients and/or children for a longer time with respect to the pre-pandemic era, and dealing with learning of children that continuing with distance education in this period. Moreover, most of working women have lost their jobs, incomes, realm of economic and social freedom, places in the public life and rights to speak and act in their life in some measures. This is because the first group suspending from both labor market and public life has mostly been composed of women by occurrence of the pandemic. In other words, "crises have a gender" 
(Korolczuk, 2020). On the other side, at the same time women who have returned to oikos from koine in one sense undergo the pandemic process with a significant endeavor and effort beside all responsibilities of oikos and all obligations of koine.

In other respects, young women forming a part of these women have to unusually re-formulate their own ontological and epistemological positionings shaped by new kinds of socio-economic and socio-cultural structures of the modern world district from their mothers and grandmothers within this process. In addition to the concern for the future caused by shrinkage of current labor market, increase of unemployment and approaching economic crises, the social and cultural reference points of the young women who are the prominent ingredients of feminism and women movement raising day by day all around the world are under threat. Especially adjourning of face-toface education at universities, which are one of the places in where their socioeconomic concerns and socio-cultural backgrounds are re-constituted as having an advantage in their life, may cause a critical change for these young women. This is because for these young women universities are not only places they go for listening lessons but also spaces provide them accumulations to strengthen their socio-economic and socio-cultural anchor points for future. For this reason, for female students the period, in which universities replaced the face-to-face education with online distance education process, signifies a very important period of time for both their daily life and academic life. Trying to continue their learning with distance education simultaneously returning their homes, staying at homes for long times and undertaking the domestic workload significantly overburdens them considerably. In addition to the psychological pressure caused by pandemic and quarantine circumstances and anxiety for the future, the difficulties originated by these burdens may cause bring hard times for female students. Therefore, for this reason, by this work, it is aimed to examine the difficulties the female students encounter within this process and the aspects of these difficulties in their life.

\section{Kaynakça / References}

Agamben, G. (2020a). Öğrencilere ağıt. (Çev. K. Cenk). Universus: Sosyal Araştırmalar Merkezi. 25 Eylül 2020 tarihinde https://uni-versus.org/2020/05/23/agambenkoronavirus-ogrencilere-agit/ adresinden erişilmiştir. 
Agamben, G. (2020b). Hayatta kalmaktan başka ahlaki değeri olmayan bir toplum nedir?. (Çev. E. B. Aslanoğlu). Universus: Sosyal Araştırmalar Merkezi. 25 Eylül 2020 tarihinde https:/uni-versus.org/2020/03/18/ceviri-agamben-mart2020/ adresinden erişilmiştir.

Altınoluk, D. (2018). Kadın olmak mı, akademisyen olmak mı?: İşte bütün mesele bu. Fe Dergi, 10(1), 58-66. 10 Ekim 2020 tarihinde http://cins.ankara.edu.tr/19 5.pdf adresinden erişilmiştir.

Ayanoğlu, Z. N. (2020). Karantina belleği: Ev içi emeğe radikal feminist bakış. Birikim / Güncel. 05.10.2020 tarihinde https://www.birikimdergisi.com/guncel/10168/karantina-bellegi-ev-ici-emege-radikal-feminist-bakis adresinden erişilmiştir.

Bilir, Z. E. (2021). Kadın emeğini feminist metodolojiyle anlamak. Kadın İşçi. 02 Mart 2021 tarihinde https://www.kadinisci.org/2021/02/23/kadin-emegini-feministmetodolojiyle-anlamak/adresinden erişilmiştir.

BM (2020a). Kovid-19 kadın ve erkekleri sosyal ve ekonomik olarak farklı etkiliyor!. 27 Eylül 2020 tarihinde https://turkey.un.org/tr/39770-kovid-19-kadin-ve-erkekleri-sosyal-ve-ekonomik-olarak-farkli-etkiliyor adresinden erişilmiştir.

BM (2020b). Politika özeti: coond-19'un kadınlar üzerindeki etkisi. 27 Eylül 2020 tarihinde https://turkey.un.org/tr/49533-genel-sekreterin-politika-ozeti-covid-19un-kadinlar-uzerindeki-etkisi adresinden erişilmiştir.

Düzen, E. ve Gezici-Yalçın, M. (2020). Yeni deneyimlerin mahali olarak salgın günlerinde ev. Birikim / Güncel. 06 Ekim 2020 tarihinde https://www.birikimdergisi.com/guncel/10167/yeni-deneyimlerin-mahali-olarak-salgin-gunlerindeev adresinden erişilmiştir.

Emil, S. (2020). Hocam, güz 2020 döneminde üniversiteler açlacak mı?. Gazete Duvar. 08 Ekim 2020 tarihinde https:/www.gazeteduvar.com.tr/yazarlar/2020/06/26/kaynayan-universite-kazani/adresinden erişilmiştir.

Gögü̈s-Tan, M. (2020). Covıd-19: Pandemi-eğitim-toplumsal cinsiyet. KEİG. 07 Ekim 2020 tarihinde http://www.keig.org/covid-19-pandemi-egitim-toplumsal-cinsiyet/ adresinden erişilmiştir.

Göker, Z. G. ve Polatdemir, A. (2019). Türkiye'de yükseköğretim kurumlarnda toplumsal cinsiyet eşitliği mekanizmalarn: Bir temel değerlendirme çalışması. İstanbul: Sabancı Üniversitesi Toplumsal Cinsiyet ve Kadın Çalışmaları Mükemmeliyet Merkezi (SU Gender) ve Research Worldwide Istanbul. 26 Eylül 2020 tarihinde https://sugender.sabanciuniv.edu/sites/sugender.sabanciuniv.edu/files/univ toplumsal cinsiyet raporu 30nisan.pdf adresinden erişilmiştir. 
Gupta, A. H. (2020). Why women may face a greater risk of catching coronavirus. The New York Times. 07 Ekim 2020 tarihinde https://www.nytimes.com/2020/03/12/us/women-coronavirus-greater-risk.html adresinden erişilmiş̧ir.

ILO (2020). Coond-19 ve toplumsal cinsiyet eşitliği. 03 Ekim 2020 tarihinde https://www.ilo.org/ankara/areas-of-work/covid-19/WCMS 745013/lang-tr/index.htm adresinden erişilmiştir.

Junaid, A. (2020). Covid-19 Hindistan'daki feminist anlatlları sonsuza dek nasıl değiştirdi?. (Çev. D. Ö. Çiçek). 5 Harfliler. 04 Ekim 2020 tarihinde http://www.5harfliler.com/covid-19-hindistandaki-feminist-anlatilari-sonsuza-dek-nasil-degistirdi/adresinden erişilmiştir.

Korolczuk, E. (2020). Krizin cinsiyeti: Pandemi günlerinde kadınlar. (Çev. H. Osmanağaoğlu). Heinrich Böll Stiftung Derneği Türkiye Temsilciliği. 05 Eylül 2020 tarihinde https://tr.boell.org/tr/2020/05/04/krizin-cinsiyeti-pandemi-gunlerindekadinlar adresinden erişilmiştir.

Saad-Filho, A. (2020). From covid-19 to the end of neoliberalism. Critical Sociology. 28 Eylül $2020 \quad$ tarihinde https:/journals.sagepub.com/doi/full/10.1177/0896920520929966 adresinden erişilmiştir.

TÜIKK (2019). Hanehalkı bilişim teknolojileri (bt) kullanım araştırmass: 2019. 02 Ekim 2020 tarihinde http://www.tuik.gov.tr/PreHaberBultenleri.do?id=30574 adresinden erişilmiştir.

TÜRK-ISS (2020). Aralık 2020 açlk ve yoksulluk stnır. 05 Ocak 2021 tarihinde http://www.turkis.org.tr/ARALIK-2020-ACLIK-VE-YOKSULLUK-SINIRI$\underline{\mathrm{d} 478752}$ adresinden erişilmiştir.

UNICEF, UN Women and Plan International (2020). A new era for girls: Taking stock of 25 years of progress. New York: UNICEF. 03 Ekim 2020 tarihinde https://www.unicef.org/media/65586/file/A-new-era-for-girls-2020.pdf adresinden erişilmiştir.

UNESCO (2020). Covid-19 school closures around the world will hit girls hardest. 03 Ekim 2020 tarihinde https://en.unesco.org/news/covid-19-school-closures-aroundworld-will-hit-girls-hardest adresinden erişilmiş̧ir.

\section{Kaynakça Bilgisi / Citation Information}

Yıldırım Şahin, E. (2021). Pandemi sürecinin kadın üniversite öğrencileri üzerindeki etkileri ve uygulanan uzaktan eğitim sürecinde yaşadıkları sorunlar. OPUS-Uluslararası Toplum Araştırmaları Dergisi, 17(Pandemi Özel Sayısı), 3245-3275. DOI: 10.26466/opus.828394 